\title{
Glaciological study in Terra Nova Bay, Antarctica, inferred from remote sensing analysis
}

\author{
Massimo FrezzotTi \\ ENEA CRE Casaccia, P.O. Box 2400, 00100 Roma A.D., Italy
}

\begin{abstract}
Analysis of satellite images (Landsat 1 MSS, 4 TM and SPOT 1 XS), of U.S. Navy aerial photographs (TMA) and of U.S.G.S. maps has made it possible to assess a number of parameters relating to the surface dynamics (between 1956 and 1990) of eight ice tongues and of two ice shelves in the Terra Nova Bay area. The study shows that between 1960-63 and 1972-73 there was a decided decrease in the areas of some of the tongues and shelves: $-53 \mathrm{~km}^{2}$ for the Aviator Glacier Tongue and $-124 \mathrm{~km}^{2}$ for the Nansen Ice Sheet. On the other hand, the areas generally increased in the period $1972-73$ to 1988. An exception to this situation is the small Hells Gate ice shelf whose area diminished by $1.15 \mathrm{~km}^{2}$ between $1956-57$ and 1988. The calculated surface velocity of the ice tongues shows that they increase from the grounding line to their outer limit. Values of longitudinal strain rate generally increase from the grounding line to just after the start of the ice tongue, after which they diminsh proceeding towards its outer limit. Integration of the areal values with radio-echo sounding data has enabled the ice discharges of the southern flow of the David Glacier $\left(12 \mathrm{~km}^{3} \mathrm{a}^{-1}\right)$ and of the Aviator Glacier Tongue $\left(0.62 \mathrm{~km}^{3} \mathrm{a}^{-1}\right)$ to be calculated. Furthermore, on the basis of the data available, basal melting values of between $25 \mathrm{~cm} \mathrm{a}^{-1}$ and $100 \mathrm{~cm} \mathrm{a}^{-1}$ ar leduced for these two ice tongues, and bottom freezing values of $20 \mathrm{~cm} \mathrm{a}^{-1}$ for the Drygalski Ice Tongue. Different spectral responses of the glacial areas have made it possible to discriminate ablation areas from those of accumulation and to differentiate various typologies of ice (glacier ice, melt lake ice, and sea ice formed at the ice shelf-ocean interface).
\end{abstract}

\section{INTRODUCTION}

The Italian Antarctic research program has been operating in the Terra Nova Bay area (Victoria Land) since December 1985. This area is on the boundary between two zones with different morphological and glaciological characteristics (Fig. 1). To the north are the mountains of northern Victoria Land with their alpinetype morphology and glacial cover in the form of névés and local glaciers (Aviator, Campbell, Random Hills and Tinker) which are not fed by the East Antarctica ice sheet. These glaciers discharge into Wood Bay and Terra Nova Bay, forming ice tongues. To the south the coast is characterized by ice tongues fed by small glaciers (the Clarke and Larsen glaciers) which drain local nunatak areas partly fed also by the peripheral part of the inland ice sheet. The major outlet glaciers of the area, David, Reeves and Priestley, which drain part of Dome Circe and of the Talos Dome (Drewry, 1983) having an area of approximately $250000 \mathrm{~km}^{2}$, unite in Terra Nova Bay. The Reeves and Priestley outlet glaciers, joining together, form the Nansen Ice Sheet (the name given on the U.S.G.S. map, though it is an ice shelf). Hells Gate is a small ice shelf, floating in Terra Nova Bay, situated between the Northern Foothills and Vegetation and Inexpressible islands.

Ice shelves and ice tongues play an important role in the dynamics and mass balance of Antarctic ice sheet. Different authors (Williams and others, 1982; Swithin-

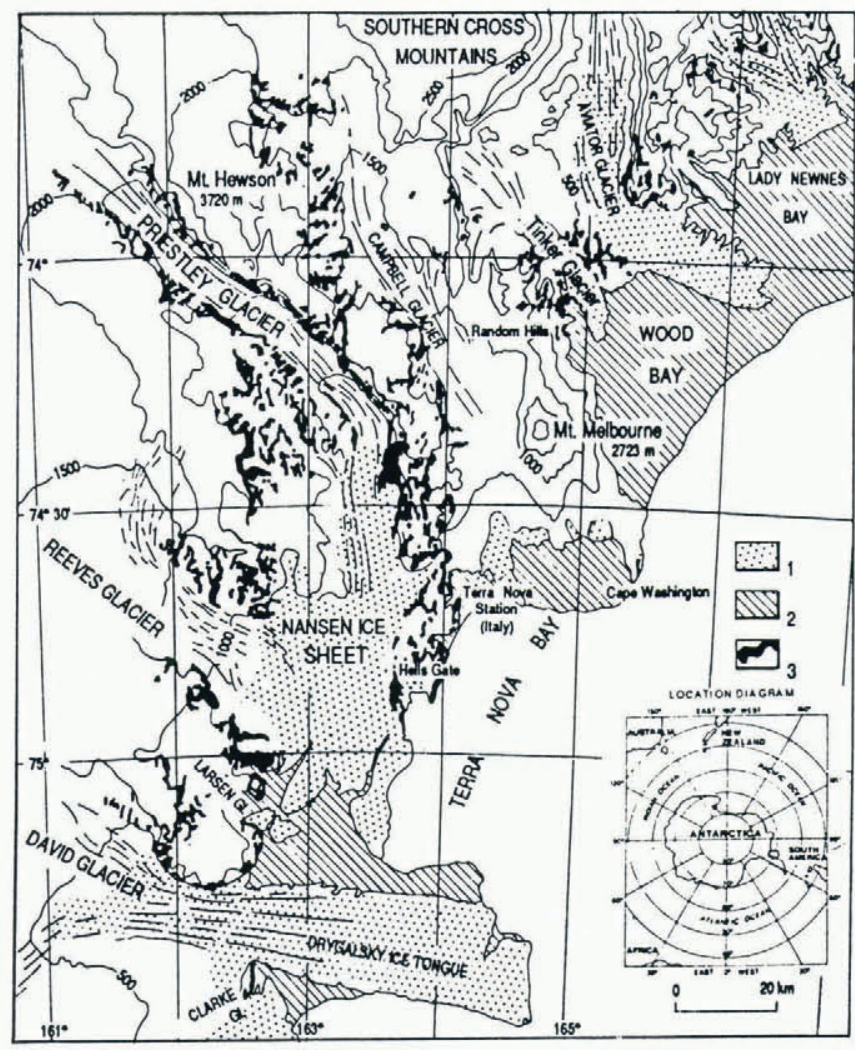

Fig. 1. Sketch map of Terra Nova Bay and Wood Bay area redrawn on the basis of U.S.G.S topographic maps of Antarctica Reconnaissance Series. Legend: 1: Floating ice shelves, ice tongues and glacier tongues; 2: Fast and bay ice; 3: Ice-free area. 
bank, 1988; MacDonald and others, 1989; Bindschadler and Scambos, 1991) have shown that reliable parameters concerning flow characters of these features (flow rate, areal and ice front variation, lateral spreading etc.) can be obtained by analysis and comparison of satellite images and air photos which have been taken several years apart. The ice tongues and ice shelves of Terra Nova Bay range in area from tens of $\mathrm{km}^{2}$ (Larsen and Random Hills ice tongues, Hells Gate ice shelf) to about $2000 \mathrm{~km}^{2}$ (Nansen Ice Sheet, Drygalski Ice Tongue).

The katabatic winds from the East Antarctica ice sheet are the most significant climatic factor in the Terra Nova Bay area (Bromwich and Kurtz, 1984). These winds blow mainly along the valleys of the David, Reeves and Priestley glaciers. Their force and persistence, mainly in winter, causes the formation of persistent annual polynya in Terra Nova Bay (Kurtz and Bromwich, 1983). Moreover, these winds are the principal element acting on the surfaces of the glacier bodies, causing high surface ablation rates with the formation of areas of blue ice, windscoops and snowdrifts.

\section{MATERIALS AND METHODS}

Aerial photographs and satellite images of Terra Nova Bay area have been acquired since 1955 and 1972 respectively. Aerial photographs were taken by the U.S. Navy with the Trimetrogon system (TMA) between 1955 and 1963 and they have been used by the U.S. Geological Survey and the National Science Foundation to compile maps of the Antarctica Reconnaissance Series at the scale 1:250000 for the Ross Sea sector. In this study, the Sequence Hills, Mount Murchison, Reeves Névé, Mount Melbourne, Mount Joyce and Relief Inlet sheets have been used. The satellite images were recorded by Landsat 1 MSS (1972 and 1973), by Landsat 4 TM (1988 and 1990) and SPOT 1 XS (1988, 1989 and 1990). Landsat 1 MSS is a first-generation satellite, with images having an normal spatial resolution (pixel size) of about $80 \times 80 \mathrm{~m}$ and four spectral bands. SPOT $1 \mathrm{XS}$ and Landsat 4 TM are second-generation satellites showing high quality geometrical definition with a spatial resolution of $20 \times 20 \mathrm{~m}$ and $30 \times 30 \mathrm{~m}$ respectively. SPOT $1 \mathrm{XS}$ has three spectral bands and Landsat $4 \mathrm{TM}$ has seven spectral bands.

With the use of Landsat $4 \mathrm{TM}$ satellite images (62/113 and 62/114 of 17 January 1990; Fig. 3) and SPOT 1 XS images $(25 / 547,27 / 547,28 / 549$ and $26 / 550$ of 19 December 1988; 24/544 and 25/546 of 2 December 1989 and $20 / 545,21 / 544 ; 21 / 547$ and $23 / 546$ of 12 January 1990; Fig. 2), two geo-referenced mosaics were created (Frezzotti, 1992; Borfecchia and Frezzotti, 1991), identifying on the images the geodetic network of P.N.R.A. (ITALIANTARTIDE) and the Survey Control Stations of the U.S. Geological Survey Maps. Georeferencing was carried out by rectifying the images in a Lambert Conformal Conic cartographic projection (Standard Parallel $72^{\circ} 40^{\prime}$ and $75^{\circ} 20^{\prime}$, WGS 72) equal to that of U.S.G.S. maps, using a linear conversion matrix with a RMS of less than two pixels. Taking these mosaics as references, the other satellite images (Landsat 1 MSS $64 / 112$ and $64 / 113$ of 28 November 1972; Landsat 1 MSS
64/113 and 64/114 of 2 January 1973; Landsat 4 TM 60/ 114 of 13 December 1988) were rectified using a linear conversion matrix with a RMS of under one pixel.

The satellite images and the maps of the ice tongues and of the ice shelves corrected in this way were analyzed and compared by digital techniques. The different geographical positions of the glacial features (ice fronts, snow drifts, crevasses, ice dolines etc.) during different years allowed evaluation of variations of surface parameters, the positions of the ice fronts and the surface velocities (Baroni and others, 1991a; Frezzotti, 1992). The main error in flow rate determinations results from the geometric resolution of the satellite (Landsat 1 MSS $80 \times 80 \mathrm{~m}$, Landsat $4 \mathrm{TM} 30 \times 30 \mathrm{~m}$, and SPOT $1 \mathrm{XS}$ $20 \times 20 \mathrm{~m}$ ) and from imprecise positioning of points caused by uncertainties in identifying identical details of the features in the two images, as Orheim and Lucchitta (1987) point out.

To investigate the ice shelf Hells Gate, we utilized the following vertical U.S. Navy photographs: TMA 325 F32, no. 70-72 (3 December 1956), TMA 365 F32, no. 289-292 (10 December 1957); TMA $2851 \mathrm{~V}$, no. 62-64 (6 November 1985); TMA $2852 \mathrm{~V}$, no. 103-106 (6 November 1985). On these we established scale with a detailed topographic survey of the dirt cones occurring at the surface of the ice shelf at Hells Gate west (Baroni, 1990). The relative positions of the dirt cones and of the ice front were delimited on the basis of the distance from reference points on land (Inexpressible Island to the west and Northern Foothills to the east). The measurements were repeated on enlargements $(\times 5)$ of both the 1956-57 and 1985 images. This procedure allowed the measurements of the flow rate and the variation of the ice front between 1956-57 and 1985 original photographs $(9 \times 9$ in). Other measurements have been obtained by comparing a subscene of the SPOT 1 XS $(27 / 547,19$ December 1988; Fig. 6) with aerial photograph (Baroni and others, 199la).

All the elaborations were carried out using the hardware and software instruments of EDI (ENEA DIGITAL IMAGERY) system.

\section{ICE TONGUES AND ICE SHELVES}

\section{Aviator, Campbell, Random Hills and Tinker}

The local Aviator, Random Hills and Tinker glaciers end in ice tongues in Wood Bay (Fig. 2), whereas Campbell Glacier ends in Terra Nova Bay (Fig. 1). These glaciers have accumulation basins (Fig. 1) varying in size between a few tens of $\mathrm{km}^{2}$ (Random Hills, $76 \mathrm{~km}^{2}$ ) and some thousands of $\mathrm{km}^{2}$ (Aviator Glacier, $7300 \mathrm{~km}^{2}$, Campbell Glacier, $4000 \mathrm{~km}^{2}$, Tinker Glacier, $1400 \mathrm{~km}^{2}$ ). The basins of these glaciers reach and exceed $3000 \mathrm{~m}$ (Mount Hewson, approximately $3720 \mathrm{~m}$ ) and they develop mainly at heights of more than $1000 \mathrm{~m}(80 \%$ of the Campbell glacier basin area develops at heights of more than $1000 \mathrm{~m}$ ). The Random Hills and Campbell glaciers have their grounding line and the start of the ice tongue more or less coinciding, while the Tinker and Aviator glaciers float for about a quarter of their length (Fig. 1).

The analysis of the position of the ice fronts (U.S.G.S. 1963, Landsat 1 MSS 1972, SPOT 1 XS 1988-89) has 


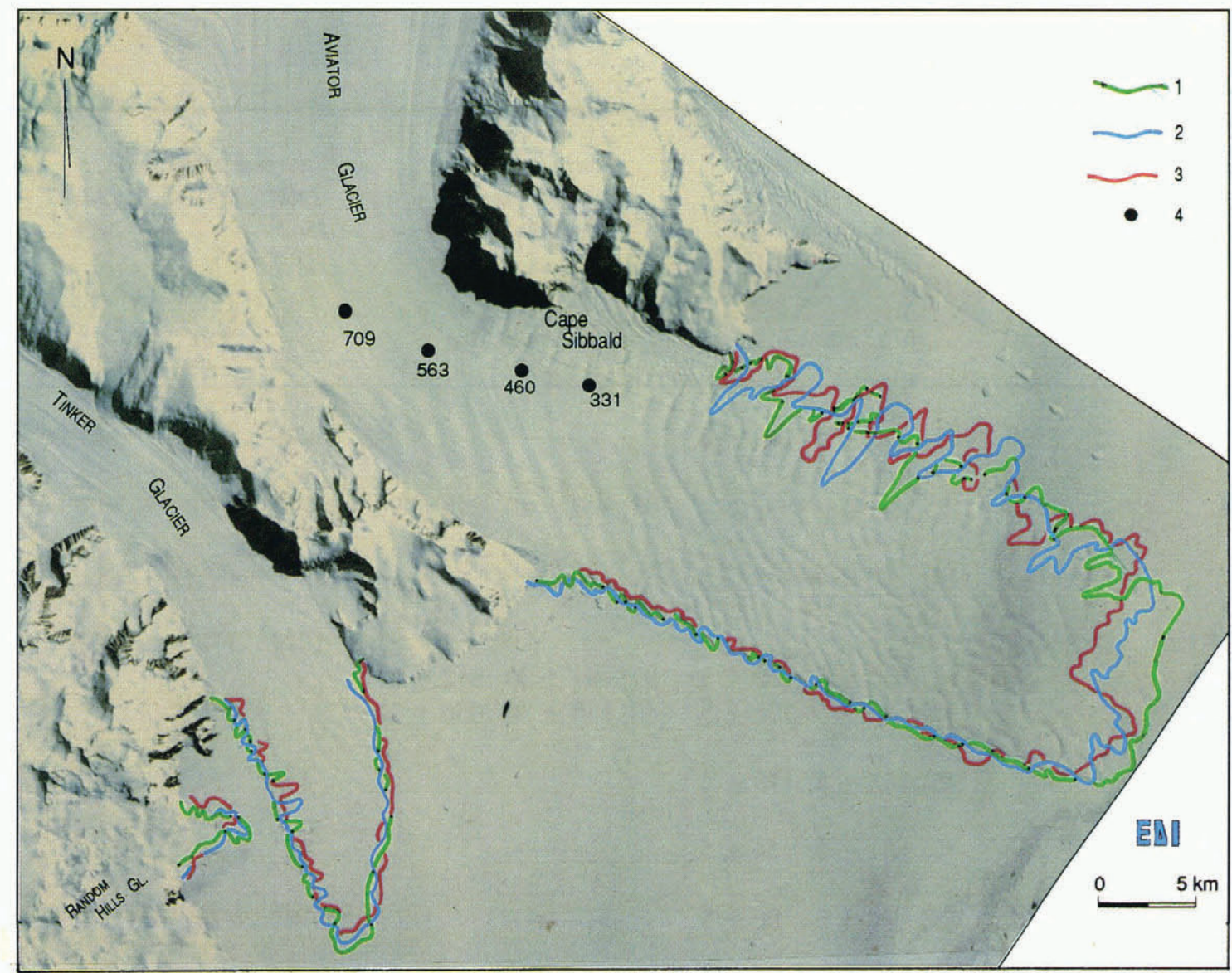

Fig. 2. Subscene of mosaic of SPOT 1 XS images (Borfecchia and Frezzotti, 1991) in false color $(R G B: 3,2,1$ ) showing the Wood Bay area. Legend: 1: Ice front in 1989 (SPOT 1 XS); 2: Ice front in 1972 (Landsat 1 MSS); 3: Ice front in 1963 (U.S.G.S. maps); 4: Radio-echo sounding in meters (Engelhart and others, 1989).

shown that the Campbell Glacier Tongue retains the same extent over time (Table 1) but not the morphology of its ice front. Such a situation could be explained by assuming that constant annual iceberg calving offsets the ice discharge. The Aviator, Random Hills and Tinker ice tongues floating in Wood Bay present significant variations in extent and morphology in the course of time (Fig. 2 and Table 1): certain elements typical of the morphology of the ice cliffs of the ice tongues are retained for tens of years (Frezzotti, 1992). For these ice tongues we have to assume periods of more than ten years of constant growth, interspersed by phases in the course of which the breaking off of icebergs reduces their area significantly. The different behaviour of the ice tongues in the two bays should be linked with the winter polynya present in Terra Nova Bay, pointed out by Kurtz and Bromwich (1983). The presence of the polynya prevents the formation of fast and bay ice around the Campbell Glacier Tongue, enabling the wave motion and the sea currents to break up the ice tongue into small icebergs. The presence of fast and bay ice through most of the year in Wood Bay permits instead a better protection and conservation of the ice tongues, which then break up when there are intense storms.

The annual flow rates of these ice tongues (Table 1) have been calculated over an average of 17 years (Landsat 1 MSS of 1972 and SPOT 1 XS of 1989) at
31 points for Aviator, five points for Random Hills and eight points for Tinker. For the Campbell Glacier Tongue it has been possible to calculate the annual flow rate (Table 1) at 33 points on two high-resolution images taken at an interval of 12 months (SPOT $1 \mathrm{XS}$ in December 1988 and December 1989). In the northern sector of the initial part of the Aviator Glacier Tongue, the calculated flow rates range from 119 to $172 \pm 5 \mathrm{~m} \mathrm{a}^{-1}$ with longitudinal strain rate values of $4.1-6 \times 10^{-3} \mathrm{a}^{-1}$. In the southern sector of the ice tongue, instead, flow rates of 145-149 $\pm 5 \mathrm{ma}^{-1}$ and longitudinal strain rates of $1.8 \times 10^{-3} \mathrm{a}^{-1}$ have been calculated. The values of the velocity $\left(175-185 \pm 5 \mathrm{~m} \mathrm{a}^{-1}\right)$ and of the longitudinal strain rate $\left(1.1-1.5 \times 10^{-3} \mathrm{a}^{-1}\right)$ in the second part of the ice tongue are homogeneous in both sectors. The rift observed in the northern part of the ice tongue (Fig. 2) seems to be linked with this velocity difference. Such behaviour is probably the consequence of an abrupt change in direction of the glacier just before becoming a tongue.

Integration of surface parameters (flow rate, width) with ice thickness values (estimated by means of the height of the surface of the ice tongue above sea level, assuming hydrostatic equilibrium) has enabled the ice discharge to be assessed for the following ice tongues: Campbell $\left(0.4 \mathrm{~km}^{3} \mathrm{a}^{-1}\right)$, Random Hills $\left(0.01 \mathrm{~km}^{3} \mathrm{a}^{-1}\right)$ and Tinker $\left(0.063 \mathrm{~km}^{3} \mathrm{a}^{-1}\right)$. For the Campbell and the 
Table 1. Surficial parameters and ice discharge

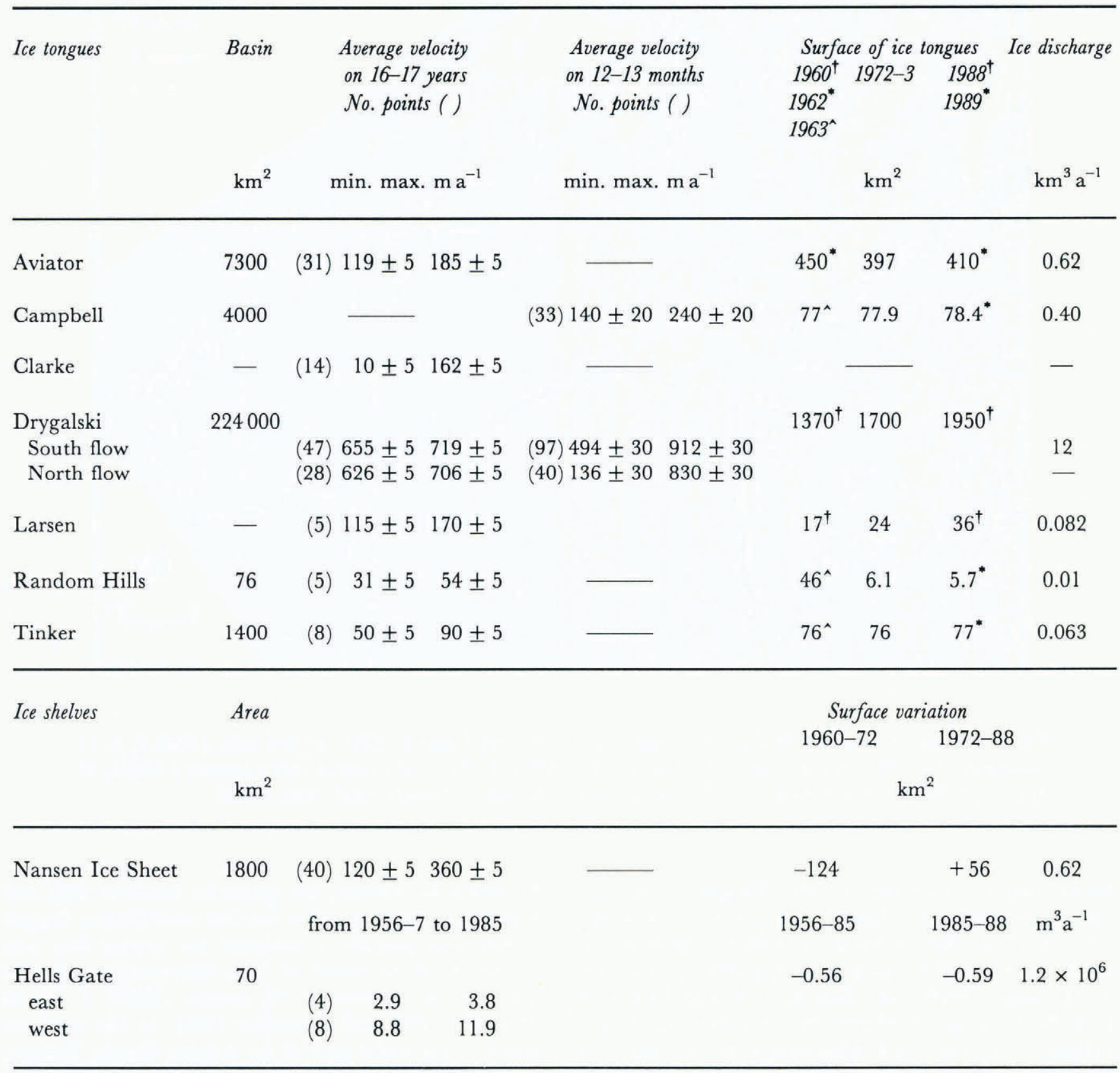

Random Hills ice tongues, as the start of the tongues coincides with the grounding line, the ice discharge corresponds to that of the glacier. The value of the ice discharge of the Campbell Glacier is in line with the value estimated by Zanon (1988). Along the final part of the Aviator Glacier (Fig. 2) some thicknesses of the ice have been measured by means of radio-echo sounding (Engelhart and others, 1989).These values agree with those estimated on the ice tongue, taking the height of the ice front above sea level, assuming hydrostatic equilibrium. Using the width, flow rate and ice thickness values, it has been possible to assess the ice discharge at a number of points of the Aviator Glacier Tongue. At the Cape Sibbald section, the ice discharge is about $0.62 \mathrm{~km}^{3} \mathrm{a}^{-1}$ and decreases $10 \mathrm{~km}$ away to $0.55 \mathrm{~km}^{3} \mathrm{a}^{-1}$, about midway along the ice tongue to $0.35 \mathrm{~km}^{3} \mathrm{a}^{-1}$ and about threequarters of the way along it to $0.30 \mathrm{~km}^{3} \mathrm{a}^{-1}$. Since the morphology of the ice tongue is very well conserved, the ice discharge loss must be correlated with the phenomena of basal melting. In Terra Nova Bay area average accumulation values of about $15 \mathrm{~cm} \mathrm{a}^{-1}$ of water equivalent (Meneghel and Smiraglia, 1991) have been measured. On the basis of morphological observations which suggest higher value of snow accumulation in Aviator Glacier Tongue than Terra Nova Bay area, we may assume a snow accumulation of about $20 \mathrm{~cm} \mathrm{a}^{-1}$ water equivalent. Using these snow accumulation and ice discharge values and the surface parameters (width, flow rate, etc.), it is possible to assess an average basal melting of approximately $20-25 \mathrm{~cm} \mathrm{a}^{-1}$, at least equal to the snow accumulation value.

\section{Clarke and Larsen}

The ice tongue of Clarke Glacier floats between the Cape 


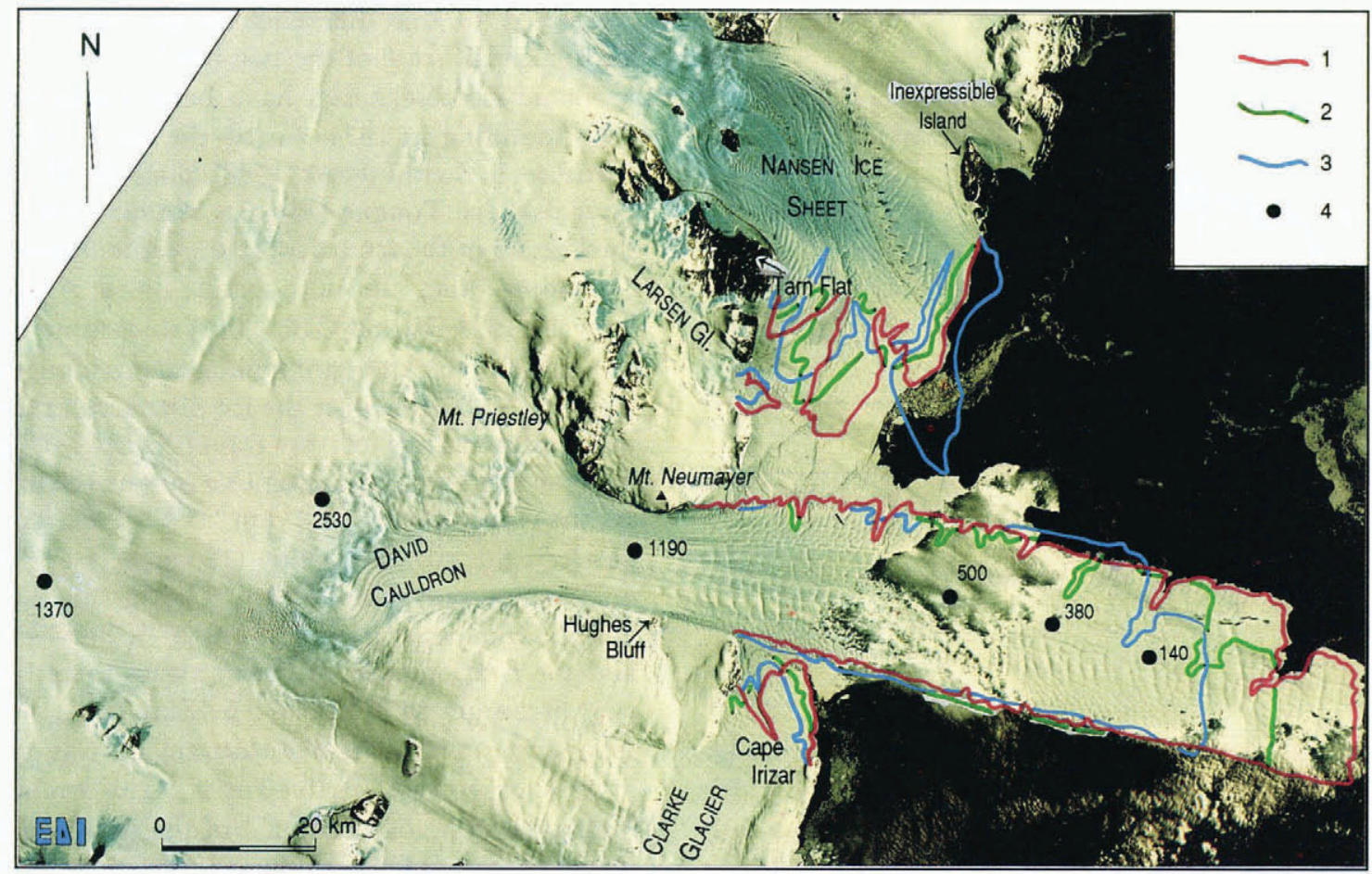

Fig. 3. Mosaic of Landsat 4 TM images (62/113 and 62/114 of 17 January 1990) in false color $(R G B: 4,3,2)$ showing the Terra Nova Bay area between Nansen Ice Sheet and Clarke Glacier. Legend: 1: Ice front in 1988 (Landsat 4 TM); 2: Ice front in 1973 (Landsat 1 MSS); 3: Ice front in 1960 (U.S.G.S. maps); 4: Radio-echo sounding in meters (Scott Polar Research Institute, in Swithinbank, 1988).

Irizar and Drygalski Ice Tongue, and the ice tongue of Larsen Glacier floats between the Nansen Ice Sheet and the Drygalski Ice Tongue (Figs 1 and 3). The Clarke and Larsen glaciers drain local nunatak areas partly fed by the peripheral part of the inland ice sheet. The geographical positions of the Clarke and the Larsen ice tongues enable fast and bay ice to remain for tens of years, protecting the ice tongues against wave motion. The morphology of their ice fronts (Fig. 3) can be recognized at an interval of tens of years (1960 U.S.G.S. maps, 197273 Landsat 1 MSS, 1988-90 Landsat 4 TM). The annual flow rates (Table 1) have been calcualted over the average of 16 years (Landsat 1 MSS 1972, Landsat 4 TM 1988) at ten points for Clarke and at five points for Larsen. For the ice tongue of Larsen Glacier the ice discharge has been evaluated as $0.082 \mathrm{~km}^{3} \mathrm{a}^{-1}$ (Frezzotti, 1992).

\section{David-Drygalski}

The Drygalski Ice Tongue is the floating tongue of David Glacier (Figs 1 and 3), the largest outlet glacier of northern Victoria Land, draining an area of the East Antarctica plateau measuring $224000 \mathrm{~km}^{2}$ (McIntyre in Swithinbank, 1988). The David Glacier is formed by the convergence of various flows under an icefall, David Cauldron. At this point it is possible to assume a variation in the trend of the substratum (McIntyre, 1985) with the stream entering a deep fjord-like valley, according to the hypothesis already made by Swithinbank (1988). The variation in trend of the substratum must also coincide with the grounding line as downstream of the icefall transverse depressions are present, characteristic of a rapidly diverging flow in floating glacier and ice tongue. Steed and Drewry (1982) point out that the David Glacier coincides with a subglacial trench which crosses the Transantarctic Mountains, linking the Ross Sea basin with the internal Wilkes subglacial basin. As the major part of the David Glacier basin rests below sea level (Drewry and others, 1983), this glacier must be regarded as a marine based one (Orombelli, 1991). The supply of the David Glacier comes from two main flows, a northern one from the Talos Dome and a southern one from Dome C (Drewry, 1983).

The Drygalski Ice Tongue retained the same ice front morphology (Fig. 3) between 1960 (U.S.G.S. map) and 1990 (Landsat 4 TM), as already pointed out by Holdsworth (1985) and Jacobs (1987). The area of the ice tongue increased by some $27.5 \mathrm{~km}^{2} \mathrm{a}^{-1}$ between 1960 and 1973 , and by some $15 \mathrm{~km}^{2} \mathrm{a}^{-1}$ between 1973 and 1990, without any evident detachment of icebergs (Frezzotti, 1992). The annual flow rates (Table 1) have been calculated over an average of 15 years (Landsat 1 MSS 1973, Landsat 4 TM 1988) at 75 points and over the average of 13 months (Landsat 4 TM, 1988-90) at 137 points (Table 1 and Fig. 4). These values are in fair agreement with those measured by Holdsworth (1985; $730 \pm 36 \mathrm{~m} \mathrm{a}^{-1}$ at about $50 \mathrm{~km}$ from the coast), MacDonald and others (1989; 670-1070 $\mathrm{m} \mathrm{a}^{-1}$ and average velocity $840 \mathrm{~m} \mathrm{a}^{-1}$ ) and Swithinbank (1988; $\left.580 \mathrm{~m} \mathrm{a}^{-1}\right)$. The southern flow has a thickness upstream of the icefall of $2530 \mathrm{~m}$ (Scott Polar Research Institute, in Swithinbank, 1988). This flow has a width of about $10 \mathrm{~km}$ in the David Cauldron (Figs 3 and 4), remaining constant to the start of the ice tongue (Mount Neumayer-Hughes Bluff section). The northern flow has a width of approximately 


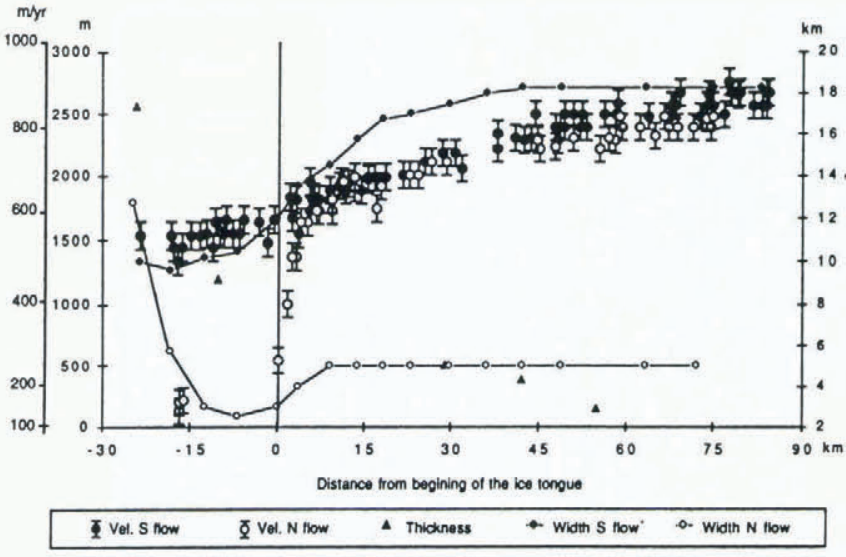

Fig. 4. Velocity, width and thickness of David GlacierDrygalski Ice Tongue.

$13 \mathrm{~km}$ at the grounding line (Mount Priestley section; Fig. 4) and at the confluence with the southern flow the width is reduced to about half $(5.75 \mathrm{~km})$ and to one-fifth $(2.5 \mathrm{~km})$ at the start of the ice tongue (Mount Neumayer-Hughes Bluff section). The velocity of southern flow in the Mount Priestley section is $550 \pm 30 \mathrm{~m} \mathrm{a}^{-1}$. At the same section the northern flow has a velocity of $136 \pm 30 \mathrm{~m} \mathrm{a}^{-1}$.

The different surface parameters (flow rate and width) show that the southern flow is the main one and that its ice discharge must definitely be more than that of the northern one. Analysis of the annual flow rates calculated in the period (December 1988-January 1990) show an increase in the rate from the grounding line to the terminal part of the ice tongue (Fig. 4). Using the regression curve of the annual velocity the longitudinal strain rates have been calculated. In the southern flow a constant decrease may be observed in the longitudinal strain rate going from the grounding line $\left(5 \times 10^{-3} \mathrm{a}^{-1}\right)$ to the terminal part of the ice tongue $\left(2.7 \times 10^{-3} \mathrm{a}^{-1}\right)$. The transverse velocity component $\left(v_{y}\right)$ of two flows increases significantly corresponding to the start of the ice tongue (from $25-108 \mathrm{~m} \mathrm{a}^{-1}$ to $80-191 \mathrm{~m} \mathrm{a}^{-1}$ ), after which it decreases $\left(25-80 \mathrm{~m} \mathrm{a}^{-1}\right)$ at $45 \mathrm{~km}$ from the start of the ice tongue. The $v_{\mathrm{y}}$ component of the southern flow is generally greater than that of the northern flow, which is in accordance with the lateral spreading trend observable on the satellite images (Figs 3 and 4).

When the glacier leaves the valley its width increases from $13 \mathrm{~km}$ (Mount Neumayer-Hughes Bluff section) to $22.75 \mathrm{~km}$ at a distance of $45 \mathrm{~km}$, as already reported by Swithinbank (1988). The northern flow doubles its rate from the start of the ice tongue (from $259 \pm 30 \mathrm{~m} \mathrm{a}^{-1}$ to $501 \pm 30 \mathrm{~m} \mathrm{a}^{-1}$; Fig. 4), within a few $\mathrm{km}$ attaining the velocity of the southern flow $\left(580 \pm 30 \mathrm{ma}^{-1}\right)$. The longitudinal strain rate of this flow between the grounding line and the start of the ice tongue is between 27 and $58 \times 10^{-3} \mathrm{a}^{-1}$, rising to values of $140 \times 10^{-3}$ only $3 \mathrm{~km}$ away from the start of the ice tongue. This value decreases to $8.8 \times 10^{-3} \mathrm{a}^{-1}$ at $7 \mathrm{~km}$ from the start of the ice tongue, and then decreases to values similar to the southern flow $\left(4.2 \times 10^{-3} \mathrm{a}^{-1}\right)$ at $10-15 \mathrm{~km}$ from the start of the ice tongue. The opening of the characteristic rifts in the northern part of the ice tongue (Fig. 3) must be correlated to this difference in the velocity and longitudinal strain rate of the two flows.

Some ice thicknesses have been measured by radioecho sounding in 1974-75 (by the Scott Polar Research Institute, in Swithinbank, 1988) along the David GlacierDrygalski Ice Tongue (Fig. 3). We may assume that the thicknesses of the ice body, at the same distance from the grounding line, do not change in a significant way between 1974-75 and 1988-90. If we assume that the flow rate and the thickness are homogeneous along the section, it is possible to calculate the ice discharge at five points of the southern flow of the David Glacier-Drygalski Ice Tongue from the grounding line (about $12 \mathrm{~km}^{3} \mathrm{a}^{-1}$ ) to $2 / 3$ of the ice tongue $\left(2.07 \mathrm{~km}^{3} \mathrm{a}^{-1}\right)$. The ice discharge between the grounding line $\left(12 \mathrm{~km}^{3} \mathrm{a}^{-1}\right)$ and the second point measured, about $30 \mathrm{~km}$ distant, shows a reduction of approximately $50 \%\left(6.35 \mathrm{~km}^{3} \mathrm{a}^{-1}\right)$. Between this point and the next one, about $40 \mathrm{~km}$ away, there is a constant ice discharge $\left(6.35 \mathrm{~km}^{3} \mathrm{a}^{-1}-6.43 \mathrm{~km}^{3} \mathrm{a}^{-1}\right)$. At the two successive points where measurement was possible, the ice discharge decreases $\left(5.4 \mathrm{~km}^{3} \mathrm{a}^{-1}-2.07 \mathrm{~km}^{3} \mathrm{a}^{-1}\right)$. The ice discharge value of $12 \mathrm{~km}^{3} \mathrm{a}^{-1}$ of the southern flow of the David Glacier is fairly well in agreement with the value of $14 \mathrm{~km}^{3} \mathrm{a}^{-1}$ of the balanced discharge assessed for the David Glacier by McIntyre (in Swithinbank, 1988).

On satellite images (Landsat 1 MSS and Landsat 4 TM) it is possible to observe an area of blue ice between the central part of the David Glacier (Mount Priestley section) and about $40 \mathrm{~km}$ from the start of the ice tongue. This indicates the presence of ablation areas, resulting from deflation and sublimation induced by katabatic winds blowing from the plateau. Downstream and upstream of this area, along the David Glacier-Drygalski Ice Tongue, it can be observed that the surface consists of snow and that the glacial morphologies are covered by snow.

In the Terra Nova Bay area average ablation values have been measured for the blue ice areas of about $20 \mathrm{~cm} \mathrm{a}^{-1}$, and accumulation values of about $15 \mathrm{~cm} \mathrm{a}^{-1}$ of water equivalant (Baroni, 1990; Frezzotti, 1992; Meneghel and Smiraglia, 1991; personal communication from M. Meneghel, 1991). Using these values for the accumulation and ablation areas of the David GlacierDrygalski Ice Tongue, the surface parameters and the ice discharge values previously calculated, the following basal melting/freezing values may be derived (Fig. 5): $45 \mathrm{~cm} \mathrm{a}^{-1}$ of melting between the grounding line and the second RES point about $30 \mathrm{~km}$ away; $20 \mathrm{~cm} \mathrm{a}^{-1}$ of basal freezing, at least equal to the surface ablation value caused by the katabatic winds, between the second RES point and the following one about $40 \mathrm{~km}$ away; melting of $40 \mathrm{~cm} \mathrm{a}^{-1}$ between this RES point and the fourth one, increasing to $100 \mathrm{~cm} \mathrm{a}^{-1}$ two thirds of the way along.

Basal freezing phenomena in the Terra Nova Bay area have already been reported by various authors for the Nansen and Hells Gate ice shelves (Baroni, 1990; Baroni and others, 1991a; Souchez and others, 1991). Baroni (1991) derives for the western ice shelf part of Hells Gate an average basal freezing value of $12-25 \mathrm{~cm} \mathrm{a}^{-1}$. The melting/freezing processes at the base of the David Glacier-Drygalski Ice Tongue must be dominated by deep thermohaline convection, as already assumed for the nearby ice shelf Hells Gate by Souchez and others (1991). 


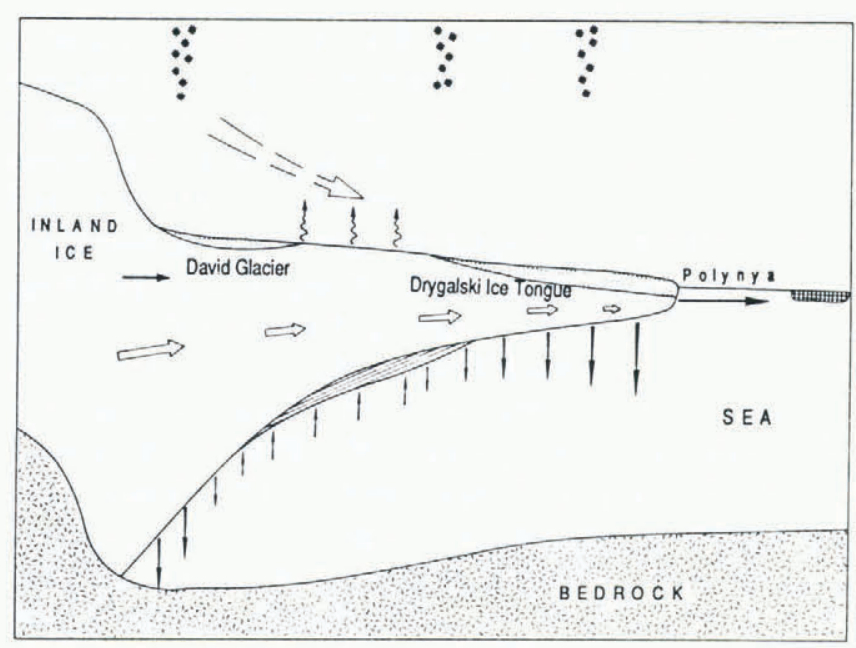

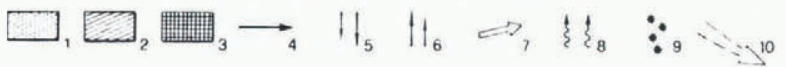

Fig. 5. Schemetic representation of David GlacierDrygalski Ice Tongue. Legend: 1: Ice derived from snowfall on the floating glacier and ice tongue; 2: Sea ice that freezes to the base of the floating glacier and ice tongue; 3: Sea ice; 4: Flow rate; 5: Basal melting; 6: Basal freezing; 7: Ice discharge; 8: Ablation induced by katabatic winds; 9: Snow accumulation; 10: Katabatic winds.

This theory has been advanced by Robin (1979) and expanded by several authors (Lewis and Perkin, 1986; Jenkins and Doake, 1991). The deep circulation beneath the floating part of David Glacier and the Drygalski Ice Tongue is driven by dense, saline water formed as a result of salt rejection from sea-ice production. Kurtz and Bromwich (1985) estimate that the Terra Nova Bay polynya produces $10 \%$ of the sea ice generated over the entire Ross Sea shelf.

\section{Nansen Ice Sheet}

The Nansen Ice Sheet has an area of approximately $1800 \mathrm{~km}^{2}$ (Baroni and others, 1991a), and is characterized at its front by characteristic rift morphologies, with the formation of large wedges (Fig. 3). These forms are due to the different velocities of the flows from the Reeves and Priestley glaciers (Baroni and others, 1991a). Analysis of the satellite images (Table 1 and Fig. 3) and of the aerial photographs has shown that between 1963 and 1972 an iceberg of about $170 \mathrm{~km}^{2}$ became detached (Baroni and others, 1991a) and that between 1972 and 1988 the ice shelf increased in area by a value equal to the annual rate of area increase due to ice discharge $\left(3.5 \mathrm{~km}^{2} \mathrm{a}^{-1}\right)$. The annual velocities have been calculated over the average of 16 years (Landsat 1 MSS 1972, SPOT $1 \mathrm{XS} 1988$ ) at 40 points (Table 1). The surface velocity increases both at the ice front and in the central portion of the Nansen Ice Sheet. It is possible to recognize different sectors of the ice shelf characterized by different surficial velocity. The portion of Nansen Ice Sheet fed by the northern sector of Reeves Glacier moves faster than both those fed by the southern sector of the same glacier and by Priestley Glacier (Baroni and others, 1991a). This velocity difference could be related to the friction of the ice shelf against Tarn Flat and Inexpressible Island and to the slopes on the ice surface of the portions fed by the Reeves Glacier $\left(3 \mathrm{~m} \mathrm{~km}^{-1}\right)$ and Priestley Glacier $\left(2 \mathrm{~m} \mathrm{~km}^{-1}\right)$. The thickness of the ice front has been estimated as about $165 \mathrm{~m}$ by means of the height of the ice cliff above sea level, assuming hydrostatic equilibrium, and thus the ice discharge at the ice front about $0.62 \mathrm{~km}^{3} \mathrm{a}^{-1}$ (Frezzotti, 1992). From the satellite images (Fig. 3) it is possible to observe that about $40 \%$ of the shelf area (approximately $720 \mathrm{~km}^{2}$ ) consists of blue ice (Baroni and others, 1991a). This is a consequence of the ablation induced by the katabatic winds from Reeves and Priestley valleys (Bromwich and Kurtz, 1984). On the Terra Nova Bay area average values of surface ablation induced by katabatic winds of $20 \mathrm{~cm} \mathrm{a}^{-1}$ have been noted (Baroni, 1990; Baroni and others, 1991a; personal communication from M. Meneghel). Considering these values it is possible to calculate a surface ablation of the ice shelf of about $0.15 \mathrm{~km}^{3} \mathrm{a}^{-1}$ (Frezzotti, 1992).

\section{Hells Gate}

Hells Gate is a small ice shelf more than $70 \mathrm{~km}^{2}$ (Fig. 6). The southernmost portion of the ice shelf, south of the latitude of the northern edge of Inexpressible Island, consists of a deflation area about $29 \mathrm{~km}^{2}$ wide. The area is affected by a strong, persistent katabatic wind which blows from the Reeves Glacier (Bromwich and Kurtz, 1982; Baroni, 1990; Baroni and others, 1991a). The ice shelf is fed by bottom freezing $\left(12-25 \mathrm{~cm} \mathrm{a}^{-1}\right)$, as shown by Baroni (1990), Baroni and others (1991b) and Souchez and others (1991).

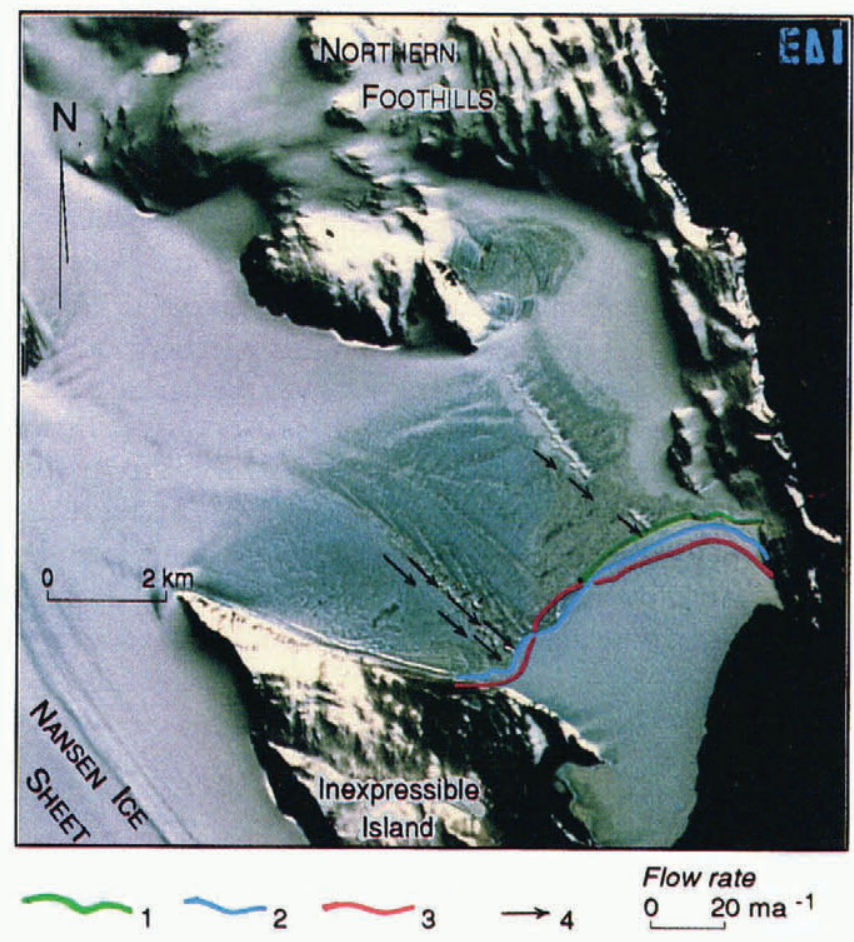

Fig. 6. Subscene of SPOT 1 XS image (27/547, 19 December 1988) in false color (RGB: 3, 2, 1) showing Hells Gate. Legend: 1: Ice front in 1988 (SPOT 1 XS); 2: Ice front in 1985 (TMA 2851); 3: Ice front in 195657 (TMA 325 and 365); 4: Flow rate. 
The satellite image (Fig. 6) shows that the ice shelf of Hells Gate is divided into three sectors (western, central and eastern) by ice-cored moraines (Baroni, 1990). The western and central sectors consist of flows from the Nansen Ice Sheet and from the southern slopes of the Northern Foothills, while the eastern sector is fed by local accumulations of snow. The central sector consists of two flows. Analysis and interpretation of the satellite images of the ice shelf, integrated with geochemical works on the ice and by glaciology (Baroni, 1990; Baroni and others, 1991 b; Souchez and others, 1991), have made it possible to discriminate (because of the different spectral response in the near-infrared and the visible bands) snow (white in Fig. 6), glacier ice (blue), the ice of melt lake (dark blue) and marine ice formed at the underside of the ice shelf (green). The boundary between the marine ice and glacier ice, well identifiable on the satellite images, is conditioned by the ablation induced by the katabatic winds. Assuming a constant average wind ablation value over the whole area of the ice shelf, the position of the boundary between the marine ice and the glacier ice in the various parts depends on the different velocities of the flows.

From the trend of this boundary it is observed that the velocities diminish from the central part toward the edges; the central area, with a higher velocity, includes the central-western flow and the eastern part of the western flow. The velocities have been calculated by analyzing the aerial photographs, over an average of 28-29 years (TMA 325,365 and 2851), at 12 points, and they are between 2.9 and $11.9 \mathrm{~m} \mathrm{a}^{-1}$ (Baroni and others, 1991a). These values are in accordance with those obtained by Baroni (1990) on the basis of the available $\mathrm{C}^{14}$ calibrated dates of the shells collected on the surface of the ice shelf.

The area of Hells Gate diminished by about $0.56 \mathrm{~km}^{2}$ between 1956-57 and 1985, and by some $0.59 \mathrm{~km}^{2}$ between 1985 and 1988 (Table 1 and Fig. 6): the total reduction was about $1.15 \mathrm{~km}^{2}$ (Baroni and others, $199 \mathrm{la}$ ). According to Orombelli (1990) the ice shelf Hells Gate has retreated several hundred meters since 1912, when a first topographic sketch map was drawn by Priestley (1923). Taking into account an ice discharge of about $1.2 \times 10^{6} \mathrm{~m}^{3} \mathrm{a}^{-1}$ the mean annual loss by iceberg calving ranges from 2.5 to $3.5 \times 10^{6} \mathrm{~m}^{3} \mathrm{a}^{-1}$ over the period $1956-$ 88. Furthermore, considering a conservative mean ablation rate about $20 \mathrm{~cm} \mathrm{a}^{-1}$ (Baroni, 1990), the ice lost at the ice shelf surface is $5.8 \times 10^{6} \mathrm{~m}^{3} \mathrm{a}^{-1}$. The resulting total ice lost by iceberg and surficial ablation can be estimated between 8.3 and $9.3 \times 10^{6} \mathrm{~m}^{3} \mathrm{a}^{-1}$ against an ice discharge value of $1.2 \times 10^{6} \mathrm{~m}^{3} \mathrm{a}^{-1}$ (Baroni and others, 1991a).

\section{CONCLUDING REMARKS}

The analysis of satellite images and aerial photographs of Terra Nova Bay area allowed us to characterize and describe ice shelves and ice tongues. Albation and accumulation areas as well as the pattern of surficial flow have been identified. The different spectral response of the glacial surfaces has made it possible to discriminate the ablation areas from those of accumulation and to differentiate various types of ice. Comparison of different images and photographs, taken at intervals of several years, has enabled the variation in size, the velocities and the spreading of the main ice tongues and ice shelves to be assessed. By integrating these data with those of RES and of ablation/accumulation, a number of ice discharge and bottom melting/freezing parameters have been evaluated. In addition, the importance of the strong, persistent katabatic winds in the dynamics of the ice shelves and ice tongues of Terra Nova Bay is evidenced.

Analysis and interpretation of the satellite images of the ice shelf Hells Gate, integrated with geochemical work on the ice and glaciology (Baroni, 1990; Baroni and others, 1991b; Souchez and others, 1991), have made it possible to discriminate (Fig. 6) due to their different spectral response in the near-infrared and the visible bands snow, glacier ice, the ice of melt lake and marine ice formed at the ice shelf-ocean interface.

The analysis of the satellite images and aerial photographs shows that between 1960-63 and 1972-73 there was a definite decrease in some of the areas of the ice tongues and the ice shelves $\left(-53 \mathrm{~km}^{2}\right.$ for the Aviator Glacier Tongue and $-124 \mathrm{~km}^{2}$ for the Nansen Ice Sheet), whereas there was an increase in the period between 1972-73 and 1988. An exception to this general situation is the small ice shelf Hells Gate, whose area diminished by $1.15 \mathrm{~km}^{2}$ between $1956-57$ and 1988. According to Orombelli (1990) this ice shelf has retreated several hundred meters since 1912, when a first topographic sketch map was drawn by Priestley (1923).

The calculated surface velocities of the ice tongues and of the ice shelves area between $3 \mathrm{~m} \mathrm{a}^{-1}$ (Hells Gate) and $912 \pm 30 \mathrm{ma}^{-1}$ (Drygalski Ice Tongue). Analysis from the velocities of the ice tongues shows that they increase from the grounding line to their outer limit. The longitudinal strain rate values generally increase from the grounding line to a short way past the start of the ice tongue, after which they decrease toward the outer limit. The Drygalski Ice Tongue presents considerable lateral spreading at the start, going from a width of $13 \mathrm{~km}$ inside the valley to about $22.5 \mathrm{~km}$ halfway along the ice tongue. The opening of rifts in the ice tongues (Aviator and Drygalski) and in the ice shelves (Nansen) is due to the different velocity and longitudinal strain rate of the flows that form these glacial bodies.

Ice discharge calculated for the glacial bodies of the Terra Nova Bay area is between $12 \mathrm{~km}^{3} \mathrm{a}^{-1}$ for the southern flow of the David Glacier and $1.2 \times 10^{6} \mathrm{~m}^{3} \mathrm{a}^{-1}$ for Hells Gate. For the David Glacier-Drygalski Ice Tongue and for the Aviator Glacier Tongue it has been possible to assess a number of basal melting values (from 20 to $100 \mathrm{~cm} \mathrm{a}^{-1}$ ), while for David-Drygalski a bottom freezing of $20 \mathrm{~cm} \mathrm{a}^{-1}$ has been assumed, at least equal to the surface ablation value induced by the katabatic winds. The presence of bottom freezing in Terra Nova Bay, already pointed out by other authors (Baroni, 1990; Baroni and others, 1991a; Baroni and others, 1991b; Souchez and others, 1991) is due to the deep circulation below the ice shelves and the ice tongues led by the dense saline waters formed as the result of salt rejection from sea ice production (Lewis and Perkin, 1986; Jenkins and Doake, 1991). Kurtz and Bromwich (1985) estimate that the polynya of Terra Nova Bay, casued by katabatic winds, produces $10 \%$ of the sea ice generated over the 
entire Ross Sea shelf. Moreover, the action of the katabatic winds induces a strong ablation on the surface of the glacial bodies with values as loss from surface of between $0.15 \mathrm{~km}^{3} \mathrm{a}^{-1}$ (Nansen Ice Sheet) and $5.8 \times 10^{6} \mathrm{~km}^{3} \mathrm{a}^{-1}$ (Hells Gate). For the last named, although the ice shelf is receding, the wind ablation is five times greater than the ice discharge at the ice cliff and represents $60-70 \%$ of the volume of ice lost by the ice shelf between 1956 and 1988 .

\section{ACKNOWLEDGEMENTS}

This work has been carried out as part of the Programma Nazionale di Richerche in Antartide (ITALIANTARTIDE) and was supported financially by ENEA through a joint research program on Antarctic Earth Science with the University of Siena (Italy). The glaciological research is coordinated by Prof. Giuseppe Orombelli.

\section{REFERENCES}

Baroni, C. 1990. The Hells Gate and Backstairs Passage ice shelves (Victoria Land, Antarctica). Mem. Soc. Geol. Ital., 43, 1988, 123-144.

Baroni, C., M. Frezzotti, C. Giraudi and G. Orombelli. 1991a. Ice flow and surficial variation inferred from satellite image and aerial photograph analysis of Larsen ice tongue, Hells Gate and Nansen ice shelves (Victoria Land, Antarctica). Mem Soc. Geol. Ital., 46, 69-80.

Baroni, C., B. Stenni and P. Iacumin. 1991b. Oxygen isotopic composition of ice samples from the Hells Gate and Backstairs Passage ice shelves (Victoria Land, Antarctica): evidence of bottom freezing. Mem. Soc. Geol. Ital., 46, 45-48.

Bindschadler, R. A. and T. A. Scambos. 1991. Satelliteimage-derived velocity field on an Antarctic ice stream. Science, 252(5003), 242-246.

Borfecchia, F. and M. Frezzotti. 1991. Satellite image mosaic of the Terra Nova Bay area (Victoria Land, Antarctica). Mem. Soc. Geol. Ital., 46, 521-523.

Bromwich, D. H. and D. D. Kurtz. 1982. Experiences of Scott's Northern Party: evidence for a relationship between winter katabatic winds and the Terra Nova Bay polynya. Polar Rec., 21(131), 137-146.

Bromwich, D. H. and D. D. Kurtz. 1984. Katabatic wind forcing of the Terra Nova Bay polynya. 7. Geophys. Res., 89(C3), 3561-3572.

Drewry, D.J., ed. 1983. Antarctica: glaciological and geophysical folio. Cambridge, University of Cambridge. Scott Polar Research Institute.

Engelhart, H., O. Schomburg and F. Thyssen. 1989. Radio-echo sounding in north Victoria Land, Antarctica. Geol. Jahrb., Reihe E, 38, 111-117.

Frezzotti, M. 1992. Fluctuations of ice tongues and ice shelves derived from satellite images in Terra Nova Bay area, Victoria Land, Antarctica. In Yoshida, Y., ed. Recent progress in Antarctic earth science. Tokyo, Terra Scientific Company.

Holdsworth. G. 1985. Some effects of ocean currents and wave motion on the dynamics of floating glacier tongues. Antarct. Res. Ser., 43, 253-271.
Jacobs, S. S. 1987. Ice fronts and icebergs in Ross and Weddell seas. Antarct. J. U. S., 22(5), 91-94.

Jenkins, A. and C.S. M. Doake. 1991. Ice-ocean interaction on Ronne Ice Shelf, Antarctica. 7. Geophys. Res., 96(C1), 791-813.

Kurtz, D. D. and D.H. Bromwich. 1983. Satellite observed behavior of the Terra Nova Bay polynya. 7 . Geophys. Res., 88(C14), 9717-9722.

Kurtz, D. D. and D. H. Bromwich. 1985. A recurring, atmospherically forced polynya in Terra Nova Bay. Antarct. Res. Ser., 43, 177-201.

Lewis, E. L. and R. G. Perkin. 1986. Ice pumps and their rates. J. Geophys. Res., 91(Cl0), 11,756-11,762.

Lucchitta, B. K. and H. M. Ferguson. 1986. Antarctica: measuring glacier velocity from satellite images. Science, 234(4780), 1105-1108.

MacDonald, T. R., J. G. Ferrigno, R. S. Williams, Jr and B. K. Lucchitta. 1989. Velocity of Antarctic outlet glaciers determined from sequential Landsat images. Antarct. 7. U. S., 24(5), 105-106.

McIntyre, N. F. 1985. The dynamics of ice-sheet outlets. 7. Glaciol., 31 (108), 99-107.

Meneghel, M. and C. Smiraglia. 1991. Preliminary data on the mass balance of the Strandline Glacier (Terra Nova Bay, Antarctica). Mem. Soc. Geol. Ital., 46, 59-67.

Orheim, O. and B. K. Lucchitta. 1987. Snow and ice studies by Thematic Mapper and multispectral scanner Landsat images. Ann. Glaciol., 9, 109-118.

Orombelli, G. 1990. Holocene environmental changes at Terra Nova Bay (Victoria Land, Antarctica). Mem. Soc. Geol. Ital., 43, 1988, 145-147.

Orombelli, G. 1991. Glaciers and glacial morphology at Terra Nova Bay: an opportunity for significant studies on environmental and climatic global changes. Mem. Soc. Geol. Ital., 46, 9-16.

Priestley, R.E. 1923. British (Terra Nova) Antarctic Expedition 1910-13. Physiography (Robertson Bay and Terra Nova Bay regions). London, Harrison and Sons.

Robin, G.deQ. 1979. Formation, flow, and disintegration of ice shelves. 7. Glaciol., 24(90), 259-271.

Souchez, R. and 8 others. 1991. Ice composition evidence of marine ice transfer along the bottom of a small Antarctic ice shelf. Geophys. Res. Lett., 18(5), 849-852.

Steed, R. H. N. and D.J. Drewry. 1982. Radio-echo sounding investigations of Wilkes Land, Antarctica. In Craddock, C., ed. Antarctic geoscience. Madison, WI, University of Wisconsin Press, 969-975.

Swithinbank, C. 1988. Satellite image atlas of glaciers of the world. Antarctica. U.S. Geol. Surv. Prof. Pap. 1386B.

Swithinbank, C. and B. K. Lucchitta. 1986. Multispectral digital image mapping of Antarctic ice features. Ann. Glaciol., 8, 159-163.

Williams, R. S., Jr, J. G. Ferrigno, T. M. Kent and J. W. Schoonmaker, Jr. 1982. Landsat images and mosaics of Antarctica for mapping and glaciological studies. Ann. Glaciol., 3, 321-326.

Zanon, G. 1989. Ricerche preliminari sul bilancio glaciale nell' area della Baia Terra Nova (Antartide). Geogr. Fis. Din. Quat., 11(1), 1988, 56-58.

The accuracy of references in the text and in this list is the responsibility of the author, to whom queries should be addressed. 